\title{
Sex Identification of the First Incubated Chicks of the Crested Ibis Nipponia nippon in Korea
}

\author{
Kyung A Kim², Jae Seok Cha ${ }^{1,3}$, Tae Jwa Kim¹, Kyung Min Kim and Hee Cheon Park ${ }^{1,2_{\star}}$ \\ ${ }^{1}$ College of Natural Sciences, Kyungpook National University, Daegu 702-701, Korea \\ ${ }^{2}$ Institute of Ornithology, Kyungpook National University, Daegu 702-701, Korea \\ ${ }^{3}$ Museum of Natural History, Kyungpook National University, Gunwi 716-822, Korea \\ ${ }^{4}$ School of Applied Biosciences, College of Agriculture and Life Science, Kyungpook National University, Daegu 702-701, Korea
}

Received February 20, 2011 /Accepted May 12, 2011

In October 2008, a pair of Crested ibis Nipponia nippon, an endangered avian species in the world, was donated to Korea from China. They have since been the subject of a successful program to incubate chicks for the first time in South Korea. This study was carried out to determine the sex of chicks from the Crested ibis through polymerase chain reaction (PCR) using the sex-related gene and the chromodomain helicase DNA binding protein (CHD) gene. The result of the CHD gene, which was used with a single set of primers and a restriction enzyme treatment after the PCR process, was more accurate in identifying the gender of the Crested ibis. In addition, we compared the CHD gene sequences with the previously reported sequences and found 1 2 different bases between females $(\mathrm{CI} 2$, CI4, CI5, and CI6) than in studies previously reporting female sequences.

Key words : Sex identification, crested ibis, Nipponia nippon, sex-related gene, CHD gene

\section{Introduction}

The population of the Crested ibis Nipponia nippon, which is a native species inhabiting Northeast Asian countries such as Korea, Japan, China, and Far Eastern Russia [14,15] has drastically decreased since 1930s due to the abuse of pesticides, poaching, and wetland decrease resulting in habitat loss [11]. Thus, the International Union for Conservation of Nature [13] has protected this bird as an endangered species and has been protected as a National Treasure (No. 198) since 1968 in South Korea. Despite all previous efforts, the three individuals of this species were last observed in the wild at Panmunjom, in the Demilitarized Zone (DMZ) during the early 1980s [1]. Fortunately, a pair of Crested ibis was introduced from China in October 2008, and following a successful program of artificial incubation of the species for the first time in South Korea. Given the necessity for conservation of endangered birds such as Crested ibis, it is crucial to identify the gender of the individuals with similar external morphs between female (ZW) and male (ZZ) to establish a self-sustainable population [8,12] for restoration of the species [3,4], for genetic diversity [5,8] and for lineage analysis [9]. Moreover,

*Corresponding author

Tel : +82-53-950-5351, Fax : +82-53-953-3066

E-mail : heecheon@knu.ac.kr raising the young chicks during the juvenile period based on sex determination encourages their familiarity, which might increase mating success rates [6].

The aim of current study was to determine the gender of each young progeny from the parents mentioned above by detecting the sex-related gene and chromodomain helicase DNA binding protein (CHD) gene, and by analyzing the sequences of the amplicons via polymerase chain reaction (PCR) of the Crested ibis for the restoration of the species in South Korea. In addition, this study recommend which is the more accurate and efficient method to identifying the gender of Crested ibis.

\section{Materials and Methods}

\section{Sampling and DNA extraction}

The bird materials for the present study included a pair of parent Crested ibis (CI1: adult male, CI2: adult female) introduced from China and their four chicks (CI3, Cl4, CI5, and CI6, respectively) domestically born in South Korea, all of which were bred at the Upo Crested ibis Restoration Center in captivity. Tissue specimens were collected from the feathers of the parent and chicks. DNAs were extracted from the tissues of the calamus tips using the DNeasy Blood \& Tissue Kit (Qiagen $\mathrm{GmbH}$, Hilden, Germany). 


\section{Amplification of sex-related DNA}

To amplify the $\mathrm{W}$ chromosome-specific DNA sequence, the primer sequences of $5^{\prime}$-CACCCTGGATTGGACAACCT ATTTC-3' (forward) and 5'-CACTCTTTCCAGGA AATC AA-3' (reverse) were used [6,9]. In addition, we designed a pair of primer set from the $\mathrm{W}$ chromosome-specific DNA sequence that was amplified from Crested ibis. The new primer sequences are 5'-ATTGACAATTTGTCT GTCTC-3 (forward) and 5'-TCTAATACTTCTTTGAATGA-3' (reverse). For PCR, 35 cycles of denaturation $\left(95^{\circ} \mathrm{C}\right.$ for $\left.80 \mathrm{sec}\right)$, annealing $\left(59^{\circ} \mathrm{C}\right.$ for $\left.90 \mathrm{sec}\right)$ and extension $\left(72^{\circ} \mathrm{C}^{\circ}\right.$ for $\left.60 \mathrm{sec}\right)$ were performed under Ex Taq polymerase (TaKaRa, Shiga, Japan) in a DNA Thermal Cycler (TaKaRa TP650, Shiga, Japan) [9]. After the PCR, the products electrophorese in 2 $\%$ agarose gel.

$\mathrm{CHD}$ genes amplification and restriction enzyme
analysis

To amplify the CHD genes, the $\mathrm{P} 1$ and $\mathrm{P} 2$ primer sequences of $5^{\prime}$-ATATTCTGGA TCTGATAGTGAYTC-3' (P1, forward) and 5'-TCTGCATCGCTAAATCCTTT-3 ${ }^{\prime}$ (P2, reverse) were used with the procedures of previous studies [3]. For PCR, 40 cycles of denaturation $\left(94^{\circ} \mathrm{C}\right.$ for $\left.30 \mathrm{sec}\right)$, annealing $\left(56^{\circ} \mathrm{C}\right.$ for $\left.15 \mathrm{sec}\right)$, and extension $\left(72^{\circ} \mathrm{C}\right.$ for $\left.15 \mathrm{sec}\right)$ were performed using Ex Taq polymerase (TaKaRa, Shiga, Japan) in a DNA Thermal Cycler (Applied Biosystems, PCR system 2700, Foster City, CA, U.S.A.). After the PCR, each amplicons of the PCR products was purified (Qiagen $\mathrm{GmbH}$, Hilden, Germany) and then each of them were concentrated. After the purification and concentration, each of reaction mixtures was subjected to three restriction enzyme (DdeI: New England BioLabs, Beverly, MA, U.S.A.; MboП and Hae III: TaKaRa, Shiga, Japan) and incubated for $2 \mathrm{hr}$ at $37^{\circ} \mathrm{C}$ [7]. In addition, these reactants electrophorese in $2 \%$ agarose gel.

To amplify the other CHD genes, the P2 and P8 primer sequences of 5'-CTCCCAAGGATGA GRAAYTG-3' (P8, forward) and 5'-TCTGCATCGCTAAATC CTTT-3' (P2, reverse) were used with the procedures of previous studies [4]. For PCR, 38 cycles of denaturation $\left(94^{\circ} \mathrm{C}\right.$ for $\left.30 \mathrm{sec}\right)$, annealing $\left(59^{\circ} \mathrm{C}\right.$ for $\left.45 \mathrm{sec}\right)$, and extension $\left(72^{\circ} \mathrm{C}\right.$ for $\left.45 \mathrm{sec}\right)$ were performed using Ex Taq polymerase (TaKaRa, Shiga, Japan). A final run of $59^{\circ} \mathrm{C}$ for $1 \mathrm{~min}$ and, $72^{\circ} \mathrm{C}$ for $5 \mathrm{~min}$ completed the program in a DNA Thermal Cycler (Applied Biosystems, PCR system 2700, Foster City, CA, U.S.A.). And then the amplicons were electrophoresised in $3 \%$ agarose gel.

\section{DNA sequencing and alignment}

The amplicons derived from PCR were subjected to a cycle sequencing (Applied Biosystems, ABI 3730xl, Foster City, CA, U.S.A.). The final DNA sequences were aligned using the ClustalW program (http://www.genome.jp). And the sex-related gene sequences were compared with the Crested ibis registered at BLAST (Accession No. AB045309, http://blast.ncbi. nlm.nih.gov/Blast.cgi) [10].

\section{Results}

W chromosome-specific DNA fragments were amplified using PCR, the sizes of which were about $307 \mathrm{bp}$ and was not detected in the male (Fig. 1A). By the result, the $\mathrm{W}$ chromosome-specific DNA band did not occur in the mature male Crested ibis (CI1), while the mature female (CI2) was showed the band. The first chick (CI3) was equal to the paternal parent $\mathrm{CI} 1$, hence the second (CI4), third (CI5) and fourth chick (CI6) were as same as the maternal parent CI2. Therefore, it was considered that $\mathrm{Cl} 3$ is male progeny, while CI4, CI5, and CI6, implicate CI2, were considered to be females. Moreover, the PCR was performed with the new single set of primers, designed from the $\mathrm{W}$ chromosome-specific DNA sequences of Crested ibis, but it was amplified from both the male and female (Fig. 1B). And the sequence of sex-related genes for the female chicks born in

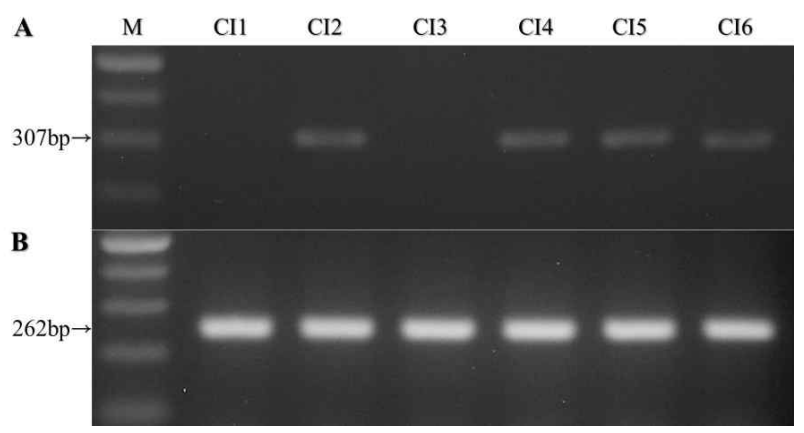

Fig. 1. Image of PCR products in which the $W$ chromosomespecific DNA sequence was amplified (A) and in which was amplified with a new designed set of primers (B). $\mathrm{A}: \mathrm{CI} 2, \mathrm{CI} 4, \mathrm{Cl} 5$, and CI6, which showed a band at about $307 \mathrm{bp}$, were considered female, and CI1 and CI3, which did not show a band, were considered male. B: The band at about 262 bp was amplified from both the male and female. PCR products contain two primers. Marker (M): 100 bp DNA Ladder. 
South Korea matched with that of the sample registered at BLAST (No. AB045309) [10].

The PCR products, amplified with P1 and P2 primers, from the male and female were digested with Dde I. In case of digestions with $M b o \Pi$ and HaeII, the product of male was almost entirely digested with two enzymes, but a slight amount of undigested products remained. On the other hand, the product of female was partially digested with two restriction enzymes, but a large amount of undigested products remained. Because of these differences, it was possible to distinguish male from female (Fig. 2A). All PCR products of chicks were digested with each of the three enzymes, respectively. The sample from the first chick $(\mathrm{CI} 3)$ was almost completely digested by the addition of three enzymes. However, the others (CI4, CI5, and CI6) were digested by $D d e I$, and only partially digested by $M b o \Pi$ and Haell. The enzyme treatment of $\mathrm{CI} 3$ was similar to that of the male, and treatments of $\mathrm{CI} 4, \mathrm{Cl} 5$, and $\mathrm{CI} 6$ were similar to that of female. Therefore, it is considered that $\mathrm{CI} 3$ was male, and CI4, CI5, and CI6 were female (Fig. 2B).

The sequences from the PCR products, amplified with P1 and P2 primers, are shown Fig. 3. The sequence of mature male (CI1) and the first chick (CI3) are as same as M1 (Japanese male) [7]. On the other hand, the sequences of

A M CIl CI2

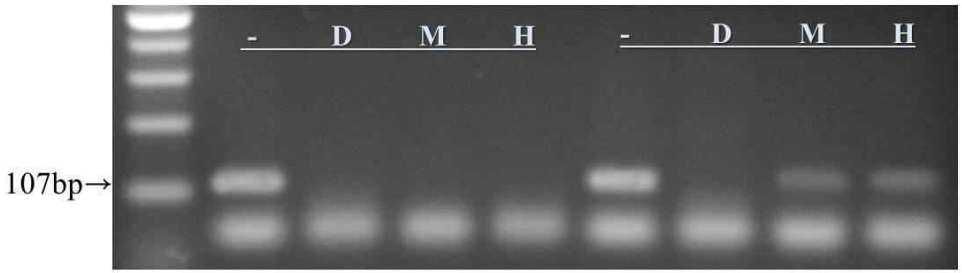

B

M

CI3

$\mathrm{CI} 4$

CI5

CI6

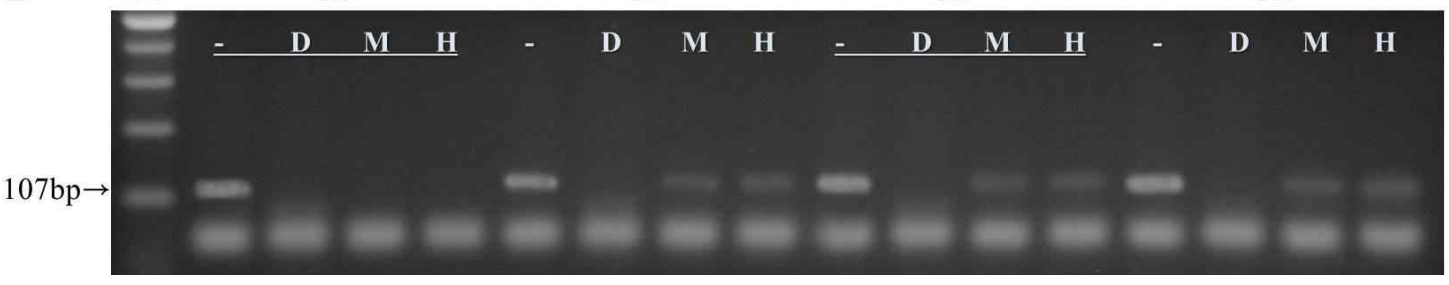

Fig. 2. Image of PCR products of adult Crested ibises (A) and the chicks (B) treatments of three restriction enzymes (Ddd, MbolI and HadII). Adult male (CI1) and adult female (CI2), the first (CI3), second (CI4), third (CI5) and forth chick (CI6) from left. Marker (M) is 100 bp DNA Ladder. The (-) means only PCR product and absence of restriction enzyme. The band size is about $107 \mathrm{bp}$ (including the two primers and $64 \mathrm{bp}$ excluding the primers).

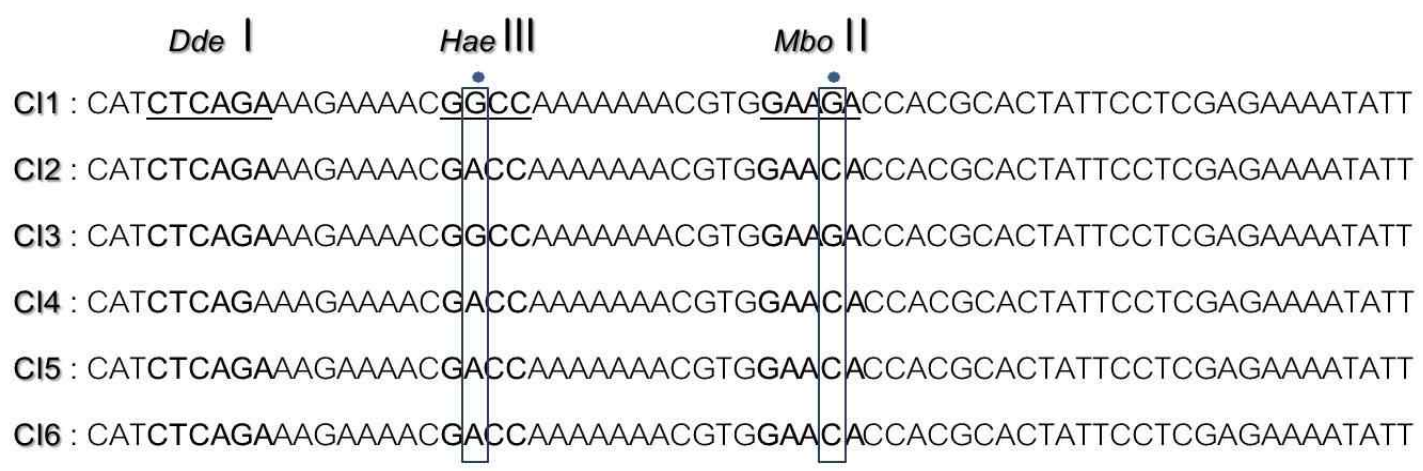

Fig. 3. PCR amplified CHD gene sequences with P1 and P2 of adult Crested ibis and the chicks. CI1 is adult male and CI2 is adult female. Moreover, the first (CI3), second (CI4), third (CI5) and forth chick (CI6), were from upstream. Dashes indicate that the sequence is equal to that of CI1. PCR primer sequences are not included. The restriction sites of enzyme Ddd, MbdI, and HadII are shown. 


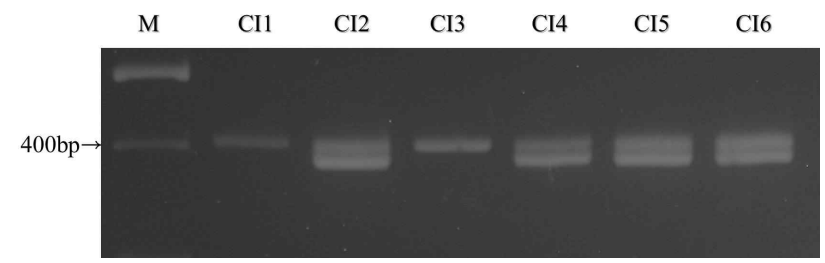

Fig. 4. Image of PCR amplified CHD gene sequences with P2 and P8 of Crested ibis in South Korea. CI1 (adult male) is one band and CI2 (adult female) is two bands. So, $\mathrm{CI} 3$ with one band is male and those with two bands, CI4, CI5 and CI6, are female. Marker (M) is 100 bp DNA Ladder. CI1: adult male and CI2: adult female. CI3: the first chick. CI4: the second chick. CI5: the third chick. CI6: the forth chick. The upper band size is about 400 bp and the lower band is about $380 \mathrm{bp}$.

mature female (CI2) and three chicks (CI4, CI5 and CI6) are different from CI1, M1, and the Japanese females (F1, F2, and F3) [10]. The restricted site of DdeI from CI2 was in accord with that of CI1, but the sites of MboI and HaeII were distinct from CI1. Because of this reason, the PCR product of $\mathrm{CI} 2$ was only partially digested with the two restriction enzymes of $\mathrm{Mbo}$ I and Haell. Moreover, CI4, CI5, and CI6 were as same as CI2 (Fig. 3).

The PCR products from the male and female were amplified with P2 and P8. The sex identification is able to known the number of fragments 1 or 2. In case of male, it showed one band of PCR product and in case of female, it showed two bands of PCR products. So it was considered that $\mathrm{CI} 1$ and $\mathrm{CI} 3$ were males, and $\mathrm{CI} 2, \mathrm{CI} 4, \mathrm{CI} 5$ and $\mathrm{CI} 6$ were females. And the difference in size between $\mathrm{Z}$ - and $\mathrm{W}$ - specific fragments amplified with the primers P2 and P8 ranges about 10 to $80 \mathrm{bp}$ [2]. So the fragments could be distinguished on $3 \%$ agarose gel (Fig. 4).

\section{Discussion}

The Crested ibis Nipponia nippon is an endangered avian species surviving from the edge of the extinction in the world, which had disappeared since 1981 in the Korean peninsula. In October 2008, a pair of Crested ibis donated from China had successfully incubated chicks for the first time in South Korea. This study used the Sex-related gene [9] and CHD gene [7] in order to identify the gender of Crested ibis, which were the first incubated chicks in South Korea. The first method, a one-off PCR was able to identify the gender of Crested ibis, was very simple, but in this study the results did not always have an expected outcome.
Therefore, the new primer set were designed from the 262 bp PCR product sequences that were amplified from the $\mathrm{W}$ chromosome-specific DNA sequence of the Crested ibis. Then PCR, using the new designed primers, was carried out again. Nevertheless, samples were amplified from both the male and female. It was considered that these sequences of from the PCR products, amplifying a portion of the $\mathrm{W}$ chromosome, were in accordance with a large part of the sequences from the $\mathrm{Z}$ chromosome [6]. The second method, which used the CHD gene with P1 and P2 and then restriction enzymes, was a little inconvenient, because it used the restriction enzyme treatment after the PCR process. It was compared with the sequences of CHD gene of from CI1 to CI6 and those of the previously reported sequences [7]. The DNA sequences of males (CI1 and CI3) and M1 consisted with each other, however the sequences of females $(\mathrm{Cl} 2, \mathrm{CI} 4, \mathrm{Cl} 5$, and $\mathrm{CI} 6)$ and $\mathrm{F} 1$ were different in 1 2 bases. It is believed that this study will provide the basic data for the genetic diversity of the Korean population of the Crested ibis and for establishing an effective species restoration strategy. The third method, which used the CHD gene with P2 and P8, was quite a bit inconvenient too. The amplified fragments of difference in size were about $20 \mathrm{bp}$, so the amplicons were barely possible to be distinguished on $3 \%$ gel. However, the results of second and third methods were always constant. Therefore, it was recommended that the second and third method were more accurate in identifying the gender of Crested ibis.

\section{Acknowledgement}

We would like to give our sincere thanks to Yanxien in China and Chinese government for their donation of the Crested ibis to South Korea and Upo Crested Ibis Restoration Center for providing the samples.

\section{References}

1. Archibald, G. W. and S. D. H. Lantis. 1981. Japanese Crested Ibis -Nipponia nippon. pp. 37-46, The present status / Rare birds of the Far East. Vladivostok.

2. Dubiec, A. and M. Zagalska. 2006. Molecular techniques for sex identification in birds. Biological Lett. 43, 3-12.

3. Griffiths, R., S. Daan, and C. Dijkstra. 1996. Sex identification in birds using two CHD genes. Proc. Biol. Sci. 263, 1251-1256.

4. Griffiths, R., C. D. Mike, O. Kate, and J. G. D. Robert. 1998. A DNA test to sex most birds. Mol. Ecol. 7, 1071-1075.

5. He, L. P., Q. H. Wan, S. G. Fang, and Y. M. Xi. 2006. 
Development of novel microsatellite loci and assessment of genetic diversity in the endangered Crested Ibis, Nipponia Nippon. Conserv. Genet. 7, 157-160.

6. Itoh, Y., A. Ogawa, K. Murata, T. Hosoda, and S. Mizuno. 1997. Identification of the sex of Oriental white stork, Ciconia boyciana, by the polymerase chain reaction based on its sex chromosome-specific DNA sequence. Genes Genet. Syst. 72, 51-56.

7. Kikuchi, M. and S. Ishii. 2002. Sex idenntification of the Japanese Crested Ibis, Nipponia nippon, by Chromodomain Helicase DNA binding protein (CHD) Gene Analysis. J. Yamashina Inst. Ornithol. 33, 189-197.

8. King, C. E. 1992. Breeding the Oriental white stork, Ciconia boyciana, at Vogelpark Walsrode, German. Zool. Gart. (N.F.) 62, 339-350.

9. Li, M., C. Ding, F. Wei, S. Meng, Y. Xi, and B. Lu. 2001. Sex-related gene and sex identification of Crested Ibis Nipponia nippon (Ciconiiformes: Threskiornithidae). Chin.
Sci. Bull. 46, 669-671.

10. Li, M., C. Ding, S. Meng, and H. B. Tamate. 2002. NCBI LOCUS No. AB045309.

11. Li, X., H. Tian, and D. Li. 2009. Why the crested ibis declined in the middle twentieth century. Biodivers. Conserv. 18, 2165-2172.

12. Murata, K., T. Hasegawa, and K. Matsushima. 1993. The cause of death of Eastern white stork (Ciconia ciconia boyciana ) in captivity. J. Jpn. Assoc. Zool. Aqua. 34, 23-27.

13. Vie, J., C. Hilton-Taylor, and S. Stuart. 2009. Wildlife in a Changing Woild - An Analysis of he 2008 IUCN Red Lis of Threstened Species, Gland, Switzerland, IUCN. pp. 180.

14. Yamashina, Y. 1975. The feeding of Japanese Crested Ibis. pp.161-164, In Templ, S. A. (ed.), Endangered Birds. Madison : University of Wisconsin Press.

15. Yamashima, Y. and G. Nakanishi. 1983. Nippania nippon. pp. 301, Newton Book. Tokyo. Kyoikusha (In Japanese).

\section{초록 : 한국 최초 인공번식에 성공한 따오기의 성별구별}

김경아 ${ }^{1,2} \cdot$ 차재석 ${ }^{1,3} \cdot$ 김태좌 $^{1} \cdot$ 김경민 ${ }^{4} \cdot$ 박희천 ${ }^{1,2}$ *

( ${ }^{1}$ 경북대학교 자연과학대학 생물학과, ${ }^{2}$ 경북대학교 조류생태환경연구소, ${ }^{3}$ 경북대학교 자연사박물관, ${ }^{4}$ 경북대 학교 농업생명과학대학 응용생명과학부)

세계적 멸종위기종인 따오기(Nipponia nippon)는 2008년 10월에 중국에서 1쌍이 도입된 후 한국최초로 인공번 식에 성공하였다. 본 연구는 따오기의 sex-related gene과 Chromodomain Helicase DNA Binding Protein gene (CHD gene)을 가지고 polymerase chain reaction (PCR)을 수행하여 새로 태어난 따오기 유조의 성별을 확인하고 자 하였다. 본 연구에서는 따오기의 성별 확인을 위해 PCR후 제한효소의 처리 방법과 P2과 P8를 이용한 PCR 방법을 실시하였을 때 더 정확한 결과가 나타남을 알 수 있었다. 그리고 CHD gene의 염기서열을 선행연구와 비교해 본 결과, 암컷의 염기서열에서 1 2 base pairs 차이가 나타남을 알 수 있었다. 